This is an electronic reprint of the original article. This reprint may differ from the original in pagination and typographic detail.

Author(s): Hyvönen, Ari-Elmeri; Möller, Frank

Title: Visualising political thinking on the screen : a dialogue between von Trotta's Hannah Arendt and its protagonist

Year: $\quad 2017$

Version:

Please cite the original version:

Hyvönen, A.-E., \& Möller, F. (2017). Visualising political thinking on the screen : a dialogue between von Trotta's Hannah Arendt and its protagonist. Journal for Cultural Research, 21(2), 140-156. https://doi.org/10.1080/14797585.2016.1266437

All material supplied via JYX is protected by copyright and other intellectual property rights, and duplication or sale of all or part of any of the repository collections is not permitted, except that material may be duplicated by you for your research use or educational purposes in electronic or print form. You must obtain permission for any other use. Electronic or print copies may not be offered, whether for sale or otherwise to anyone who is not an authorised user. 
Visualizing Political Thinking on the Screen: A Dialogue between Von Trotta's Hannah Arendt and Its Protagonist

\author{
Authors \\ Ari-EImeri Hyvönen (corresponding author), doctoral candidate, University of Jyväskylä, Finland. \\ arhyvone@jyu.fi \\ Frank Möller, Senior Research Fellow, Tampere Peace Research Institute, School of Social \\ Sciences and Humanities, University of Tampere, Finland, and Co-convenor ECPR Standing Group \\ on Politics and the Arts.
}

Acknowledgement. This work was supported by the Finnish Cultural Foundation and the Emil Aaltosen säätiö

\begin{abstract}
This article analyzes Margarethe von Trotta's film Hannah Arendt: The Woman Who Saw Banality in Evil through its protagonist's own writings on visual culture, visibility and invisibility in the context of political thinking. We start by clarifying Arendt's understanding of political theory as an activity aiming to provoke thinking. We then discuss systematically the visual language of the film and offer a typology of its representations of political thinking, subdivided into a part on internationalization and one on externalization (dialogue). We emphasize von Trotta's reliance on a negative approach, i.e. the representation of thinking through the absence of any other activity while thinking, capitalizing on the power of the invisible. However, the film and its director do not entirely succeed in engaging viewers politically. This is so because, first, the film's lack of conceptual innovation renders difficult the emergence of subject positions on the part of viewers other than consumers of established opinion. Secondly, the film insufficiently to audio-visualizes the external-communicative dimension of Arendt's political thinking: a dialogue in which viewers can participate and in the course of which what seemed to be established through political thinking gets deconstructed and subsequently re-ordered. Finally, we emphasize the importance of a cinema of thinking in our current political environment that seems to be increasingly characterized precisely by the absence of political thinking.
\end{abstract}

Keywords. Hannah Arendt, visibility, cinema, Margarethe von Trotta, theory, visualization 


\section{Visualizing Political Thinking on Screen: A Dialogue between Von Trotta's Hannah Arendt and Its Protagonist}

\section{Introduction}

It is a well-known story. In 1960, Hannah Arendt heard that Adolf Eichmann was to be put on trial in Jerusalem. She decided almost immediately that she needed to attend the trial as this seemed to be the last opportunity to see a major Nazi criminal "in the flesh." Her conclusions, reported for The New Yorker, are (in)famous: Eichmann, she thought, was "terribly and terrifyingly normal" - his evil deeds were not the product of satanic malevolence but instead were best described as "banal." This is where the story breaks apart and "the controversy" - as the episode was known in intellectual circles of New York at the time - begins. It raged many years after the publication of Arendt's Eichmann in Jerusalem: A Report on the Banality of Evil in 1963. Fifty years later, it is with us again. Margarethe von Trotta's 2013 film Hannah Arendt ${ }^{2}$ - originally titled The Controversy - rehearses both Arendt's experience at the trial and the subsequent, severe attacks on her views. Perhaps not surprisingly, the film has reignited the controversy, giving skeptics opportunity for launching yet another attack against Arendt, the gist of the argument being that even though Arendt might have revealed something essential about the nature of evil, she nevertheless "got Eichmann wrong." We argue, however, that many critics, too, "got it wrong" by focusing attention not on the film and the portrayal of thinking in it (as they were supposed to do), but on Arendt's assessment of Eichmann. As David Rieff (2013) has written, in the film "the core of [Arendt's] effort to understand and manage some kind of account of Eichmann is rightly portrayed as being about the essential role of thinking in any decent politics or morality."

In this article, we offer a political reading of the film by looking at Hannah Arendt the film through its real-life protagonist's own writings on visual culture, visibility and invisibility in the context of

\footnotetext{
${ }^{1}$ Director Margarethe von Trotta (born 1942) is closely associated with New German Cinema, an umbrella term for independent, socially and politically critical filmmaking following the Oberhausen Manifesto of 28 February 1962. Her films include The Second Awakening of Christa Klages (1978), Marianne and Juliane (1981), Rosa Luxemburg (1986) and Vision (1991).

${ }^{2}$ Hannah Arendt: The Woman Who Saw Banality in Evil. Director: Margarethe von Trotta. Screenplay: Pamela Katz and Margarethe von Trotta. Cast: Barbara Sukowa (Hannah Arendt), Janet McTeer (Mary McCarthy), Julia Jentsch (Lotte Köhler), Axel Milberg (Heinrich Blücher), Nicholas Woodeson (William Shawn), Ulrich Noethen (Hans Jonas), Michael Degen (Kurt Blumenfeld) and others. Director of Photography: Caroline Champetier. Producers: Bettina Brokemper and Johannes Rexin. Zeitgeist Films, 2012, 113 minutes.
} 
political thinking. ${ }^{3}$ By doing so, we contribute to ongoing scholarly debates in visual culture studies on both the relationship between the visible and the invisible and that between cinema and thinking (e.g. Mitchell, 2011; Connolly, 2002, pp. 92-99; Shapiro, 2009). Our questions here include: is it possible to visualize political thinking in general and Arendt's thinking in particular? Should a movie about thinking also be thought-provoking? If so, by what means? If not, is it just a film, politically largely inconsequential? Throughout the article, we are going to address our subject matter as a dialogue between Hannah Arendt and Hannah Arendt. In the light of Arendt's writings, we offer a critical investigation of, first, the film's reception and, secondly, von Trotta's attempt to visualize thinking. We offer a typology of political thinking, subdivided into a part on internalization and another on externalization (dialogue). We argue that the film is fairly compelling as to the visualization of the protagonist's thinking in terms of internal thought-processes. We suggest that the less obvious, the less didactic such visualization is, the more likely it is to make the audience engage, not only with the film but also with the deeper layers of thinking the film is meant to represent. We emphasize von Trotta's negative approach to thinking, i.e. the representation of thinking through the absence of any other activity while thinking, capitalizing on the power of the invisible. We assume that most viewers do not visit the cinema in order to be exposed to a political lecture; to some extent, then, viewers have to be tricked into engagement with Arendt's (and von Trotta's) political thought. The director's negative approach is fairly convincing.

However, the film does not entirely succeed in engaging viewers politically. This is so because the representation of the external-communicative dimension of Arendt's political thinking falls short. We argue that director von Trotta's focus on the visualization of (invisible) political thinking makes her neglect - or underutilize - one equally important and indeed indispensable aspect of Arendt's approach to political thinking: the kind of conversation or "truthful dialogue" with others that plays a constitutive role in the development of thoughts and ideas, and in the course of which that which seemed to be established through political thinking gets deconstructed and subsequently re-ordered (e.g. Arendt, 2005, pp. 19-20; Arendt, 1978, p. 189). Given the intellectual environment within which Arendt moved and thought, this aspect could potentially have been visualized relatively easily. While we are not in the position to judge, from a film-critical perspective, whether the film succeeded or failed, we would argue that the director did not take advantage of all possibilities her

\footnotetext{
${ }^{3}$ Throughout this article, Hannah Arendt (in italics) refers to the film, Hannah Arendt (without italics) or Arendt refers to the political theorist, "Hannah Arendt" refers to the character Hannah Arendt in the film (played by Barbara Sukowa). Hannah/Arendt indicates that it is occasionally difficult to differentiate the one from the other.
} 
subject matter would have offered, making it difficult for viewers to become involved in Arendt's evolving train of thoughts on evil in a position other than mere recipients of Arendt's messages.

In our engagement with the film we focus on Thinking, the first volume of Arendt's unfinished The Life of the Mind (Arendt, 1978a; henceforth referenced as LMT), because it is here that we find her most explicit engagements with questions pertaining to visibility and invisibility. In LMT (p. 71), Arendt writes that "the main characteristic of mental activities is their invisibility." This invisibility raises supreme obstacles to anyone wanting to show such mental activities as thinking in a film ${ }^{4}-$ obstacles the director was aware of. In an interview, von Trotta notes that "People who are writing can't understand the problem for a filmmaker to put thinking into images" (Lybarger, 2013). In another interview, she describes her initial response to the suggestion to make a film about Arendt as follows: "My first reaction was, how can I make a film about a philosopher, someone who sits and thinks?" (Kaplan, 2013) Had von Trotta and the screenwriter Pamela Katz blindly followed Arendt's descriptions of thinking, Ariella Azoulay quips in a recent article, the film "would have amounted to a dark screen most of the time" (Azoulay, 2015, p. 123). Babette Babich relatedly asks: "can one in fact make a film on the life of the academic mind?" After discussing various achievements of von Trotta's movie, she answers her question somewhat negatively: "the filming of thinking remains elusive" (Babich, 2014, p. 21).

Arendt also noted that mental activities "come into being ... through a deliberate withdrawal from appearances" (LMT, p. 75). Thinking is always "out of order," because it interrupts our visible activities in the world of appearances (LMT, p. 78). Arendt, furthermore, emphasized the invisible nature, not only of thinking itself but also of its object - thinking deals with the invisible aspects in experience (e.g. Arendt \& Heidegger, 2004, p. 174). It is arguable, then, that the best way of representing political thinking in a film is not by making it visible but, rather, by respecting its invisibility and capitalizing on the power of the invisible to motivate imagination. As W.J.T. Mitchell (2011, p. 84) writes in (but not limited to) a different context, "the invisible and the unseen has, paradoxically, a greater power to activate the power of imagination than a visible image." However, it is our argument that von Trotta's visualization of Arendt's political thinking by not visualizing it, focusing on one "who sits and thinks," might have been even more thoughtprovoking if more emphasis had been put on conversation - both actual dialogue with her friends

\footnotetext{
${ }^{4}$ Some critics disagree. Richard Brody (2013) writes that "the work of thinking is easy, almost effortless, to show - it's what almost every movie is made of."
} 
and - as an act of artistic freedom - some form of externalization of what Arendt calls the "silent dialogue between me and myself" (Arendt, 2003, p. 205).

\section{Eichmann in Jerusalem Re-visited}

The film Hannah Arendt presents a conventional approach to filmmaking largely devoid of cinematic experimentation, innovation or surprises. The film provokes attention not by its aesthetics but, rather, by the brilliance of its main actor's performance (Barbara Sukowa). It also provokes attention by the substance of what the protagonist has to say, even more than fifty years after the Eichmann trial. It is one of the purposes of the film, in addition to celebrating an extraordinary human being, to explain why she said what she said. The film starts with a short scene of Eichmann's abduction in Argentina and some longer scenes portraying Arendt's life and work in New York where she learns about the forthcoming trial and decides to visit Jerusalem to witness Eichmann "in the flesh" and write a report for The New Yorker. After a short flashback where "Martin Heidegger" introduces "Hannah Arendt," a young student in Marburg, into thinking as solitary business, the film moves for approximately twenty minutes to Jerusalem. True to her ideas on the nature of political thought, Arendt, despite her earlier writings on totalitarianism, did not bring a ready-made approach with her to Jerusalem simply to "apply" it to Eichmann. Rather, she started developing her understanding of Eichmann on location when witnessing the trial.

Film subjects are always "beings with multiple possibilities of becoming" (Shapiro, 2009, p. 8) and "Hannah Arendt" is no exception. The scenes in Jerusalem - witnessing the trial, seeing Eichmann (mainly, but not exclusively) on TV monitors in the pressroom, conversing with friends and so on aim to make plausible why one possibility of becoming among others - and one possibility of understanding Eichmann among others - gained the upper hand. These scenes form what may be called the film's - and its main character's - formative moments, revisited throughout the film in memory flashbacks mostly in the form of inner, occasionally multiple voices "Hannah Arendt" listens to while thinking. However, this making-plausible does not fully trigger critical cinematic thinking that "aesthetically oriented approaches to life-worlds" are said to be capable of generating (Shapiro, 2015, p.1). This is so because Hannah Arendt - in contrast to Hannah Arendt the political theorist - does not offer "conceptual innovation," identified by Michael Shapiro as the condition of possibility for thinking (in contrast to "the mere recognition of established opinion or the extrapolation from established versions of facticity") (Shapiro, 2015, p. 10). 
The scenes in Jerusalem can be seen as the condition of possibility for the protagonist's developing sense of evil-doing as banal. Compared with these scenes and the visualization of thinking (see below), all other episodes of the film are of only secondary importance in our context: the dramatic opening (Eichmann's abduction by Mossad agents), the young Arendt's affair with Heidegger, a strange, fictional ambush scene (see Rieff 2014), and even "the controversy," consuming the second half of the film, triggered by the publication of Arendt's report. However, most of the literature discussing Hannah Arendt focuses attention precisely on Arendt's Eichmann book, Eichmann in Jerusalem. While understandable, this limited focus leaves us with little or no tools with which to address many of the questions the film and Arendt's original thoughts evoke. The film was critically acclaimed but at the same time strongly criticized, albeit often in terms reminiscent of the controversy revolving around Arendt's original series of articles on the Eichmann trial, the story of which serves as the main subject of the film thereby to some extent inviting such criticism. Thus, although camouflaging as film criticism, some of the review articles cannot be considered critical engagements with the film but rather re-enactments of "the controversy" with the aid of recent historical scholarship on Eichmann (see Kaplan, 2013; Rieff, 2013; Lilla, 2013; Assheuer, 2013). Special emphasis was put, yet again, on her controversial assessment, emphasized in both the film's subtitle (The Woman Who Saw Banality in Evil) and many reviews, that evil-doing can be - and in Eichmann's case in fact was - "banal," and her equally controversial judgment of the Jewish Councils. Often, the criticism is based on a straw man version of Arendt's argument, attacking her for positions she never held, and particularly reducing her description of Eichmann into an easily refutable simplification. In addition, this approach is certainly irrelevant when considering the film as a film about Arendt and the process in the course of which Eichmann in Jerusalem came into being. ${ }^{5}$ It does not illuminate the visualization of political thinking either.

Richard Brody, writing in The New Yorker (the journal that had printed the original Eichmann in Jerusalem series), takes as standard for his evaluation of the film his own interest in the illumination of "events of great import" by means of "the small, daily actions from which they arose." Brody complains about von Trotta's preservation of "Arendt's dignity to the point of dehumanization, depriving the protagonist of any trait that could render her ridiculous" (Brody, 2013). Reducing people to their dignity has indeed been identified in recent writings on photography as a danger inherent in current image-making that tries to avoid some of the mistakes

\footnotetext{
${ }^{5}$ Lilla (2013) acknowledges that integrating into the film "what we know about [the Eichmann case] now ... would have violated the film's integrity." He nevertheless integrates what we know now in his critique of the film.
} 
early social-documentary photography is alleged to have made (Dyer, 2007, p. 103). Criticizing Hannah Arendt for "offering little intellectual substance" and even castigating the film as "a sort of soft-core philosophical porn," Brody, borrowing legitimacy from Claude Lanzmann's film The Last of the Unjust, ultimately directs his attention to his main targets, Hannah Arendt, especially her interpretations of Eichmann and of the role of the Jewish Councils, and von Trotta for representing Arendt "as correct in her claims" and "absolutely right." Brody detects "one of the signs of [the movie's] artistic failure" in its "sanctimonious depiction of 'thinking' as something greater than what the regular run of people do." He does not criticize the visualization of thinking or a specific form of visualization but rather the elevation of thinking to "a special category of activity" (Brody, 2013). If, however, Arendt did see thinking - political thinking - as a special kind of activity, why should the director, interested in Arendt's life - "I make films about people that I like or that interest me," von Trotta told Kaplan (2013) - disagree? After all, Hannah Arendt is a biopic, not a historical documentation, and its director is - understandably perhaps - not particularly interested in the deconstruction of its - and her - heroine. More generally speaking, Brody moves too easily between the failures of the thinker depicted and the director doing the depicting. Arendt certainly saw thinking as a "special category of activity" but forcefully attacked any position granting the capacity for exercising this activity only to an elite group of people. If the film breaks with Arendt's convictions on this score - and this is by no means self-evident - then that counts as a shortcoming of the film, not of Arendt.

Stating "the obvious," Rieff writes that "in a film about ideas, about thinking, the quality of the thought - the truth or falsity of the ideas - has to be central." From Arendt's own perspective, however, this is the wrong question to ask. Building on the Kantian distinction between Vernunft (reason) and Verstand (intellect), she insists that reason - the capacity for thought - does not operate on the basis of truth and falsity: "The need for reason is not inspired by the quest for truth but by the quest for meaning. And truth and meaning are not the same" (LMT, p. 15; emphasis in original). Political thinking, in particular, is not for Arendt an activity that seeks to produce true ideas. Rather, political thinking takes its bearings from the "incidents of living experience," the events taking place in the world inhabited by a plurality of human beings, and inquires into the meaning of these events (e.g. Arendt, 2006, pp. 14-15; LMT, p. 78, 166). This process of analyzing meaning - the "invisible that is specifically given in each experience" - is an endless one, and by nature produces only tentative results (Arendt, 1979, p. 338; Arendt \& Heidegger, 2004, p. 174; see also Hyvönen, 2014). Arendt's attempt, in her writing or teaching, was not to instruct others on "what to think or which truths to hold," not to speak of advocating politics of a particular kind. 
Instead, she sought to provoke thinking as such so that "when the chips are down" we would be a little more prepared to think critically and form judgments by considering issues from a plurality of viewpoints (Arendt, 2006, pp. 14-15; Arendt, 1979, p. 309).

If we read Rieff's argument more favorably as a question about "plausibility" - broadly construed of Arendt's interpretation, we can nevertheless ask if it is really the director's job to make such a judgment and if so, on what grounds? Put differently, would it not be the director's job to represent her story in a way that enables the viewer to make a qualified judgment regarding the events and the ideas outlined in the film? Could it not equally be argued that in a film about ideas, about thinking, a director's central task is, not to judge the quality of thought of his or her protagonist but to make the audience understand why a character thought what he or she thought, be it right or wrong? Is it not the director's task to show the process in the course of which a thought comes into being? But even if one answers this question in the affirmative, the director still failed, according to Mark Lilla, and she failed because "we," the audience, "don't see her [Arendt] arriving at her position through thinking. ... Barbara Sukowa smokes and rifles through documents and stares into space like a silent picture star, but we get no sense of the play of a mind" (Lilla, 2013). ${ }^{6}$ Roger Berkowitz (2013b) disagrees. He concludes that the film "makes visible how and why Arendt concluded that evil in the modern world is done neither by monsters nor [pace some of Arendt's accusers] by bureaucrats." It is to this kind of disagreement that our typology of thinking, presented below, is a response.

Given Arendt's view that "we have to see in order to perceive what we cannot see" (Arendt \& Heidegger, 2004, p. 174), it makes sense that von Trotta incorporates into the film's narrative footage from the actual trial. This incorporation increases the film's authenticity and gives the audience the possibility of seeing and witnessing Eichmann (almost) in person, ${ }^{7}$ giving ground to Berkowitz's statement about giving us a chance to see how and why Arendt came up with her conclusions. The movie seeks to visualize thinking (on the part of Arendt) and, relying on the original footage, its absence (on the part of Eichmann who is seen taking notes during the trial [33:06-33:11]). The film tries to make plausible the connection between the (perceived) absence of thinking (Eichmann as seen by Arendt) and Arendt's translation of this perception into judgment: evil-doing is banal. In one of the strongest juxtapositions of the film, Arendt's main judgment,

\footnotetext{
${ }^{6}$ Lilla acknowledges that film "lacks resources for conveying the dynamic process of weighing evidence, interpreting it, and considering alternatives."

${ }^{7}$ On this understanding of being a witness, decoupled from comtemporaneity, see Lindroos and Möller (forthcoming).
} 
revealed when she is reading a paragraph from the manuscript to her assistant - "he [Eichmann] was simply unable to think" (1:03:49) - is seemingly decoupled from her memories of the trial. These memories are activated in the film a minute before the above quotation when "Hannah Arendt," at home, lying on the couch, smoking, hears inner voices from the trial, including a dialogue between the prosecutor and Eichmann (1:02:25-1:02:48):

Prosecutor: You claim you weren't a normal recipient of orders. You thought about what you were doing. Didn't you say that?

Eichmann: I don't believe so, no.

Prosecutor: You didn't think about it?

Eichmann: Sorry?

Prosecutor: You didn't think about it? You were an imbecile. You didn't think at all?

Eichmann: Think?

Prosecutor: Yes.

Eichmann: Of course I thought about what I was doing.

Prosecutor: $\quad$ You were not an imbecile. ${ }^{8}$

Arendt, following Socrates and Heidegger, refers to thinking with the metaphor of wind. Like the wind, thought cannot be seen, nor can it be caught. At its purest, thinking always undoes its previous results: "It is in this invisible element's nature to undo, unfreeze, as it were, what language, the medium of thinking, has frozen into thought - words (concepts, sentences, definitions, doctrines)" (LMT, p. 174). This anti-doctrinal character of thinking is indeed behind Arendt's perception of Eichmann's inability to think, his thoughtlessness. The problem was not that he would have been a mere cog in a machine. Rather, the feature that most stroke Arendt in Eichmann's character was his constant use of clichés, stock phrases and so forth (LMT, p. 4). In a word, there was no sign of the "destructive" results of the wind of thought in Eichmann. Hence, while thinking per se is invisible, the lack of thought may sometimes manifest itself through behavior that is utterly banal. Eichmann insists that: "mitgedacht habe ich selbstverständlich - of course I thought about what I was doing." "Hannah Arendt" opens her eyes (1:02:49), seemingly concluding that "he (Eichmann) was simply unable to think." In the film, the thinking process that led to this conclusion is not accessible. The conclusion, for this reason, seems like what Lilla (2013) calls "a vision." Taking into account Arendt's writings, however, we can conclude that Eichmann's insistence on

\footnotetext{
${ }^{8}$ This part of the original interrogation was conducted in German. We follow the film's English subtitles and ignore here that mitdenken and denken are not identical.
} 
having thought about what he was doing precisely reveals his lack of thinking understood as permanent investigation, rather than simple unthinking confirmation, of one's earlier thoughts.

\section{Visibility and Invisibility}

“A woman stares at the ceiling, smoking a cigarette. This is Hannah Arendt, thinking.” (Sari, 2014)

The secondary literature on Arendt has approached questions pertaining to visibility and invisibility most often from the perspective of the public space and the common world. Indeed, for Arendt, the whole fabric of human reality is dependent on the interplay between visibility and invisibility: "For us, appearance - something that is being seen and heard by others as well as by ourselves constitutes reality" (Arendt, 1998, p. 50). ${ }^{9}$ In Arendt's work before the publication of The Life of the Mind, the question of visibility and invisibility was primarily approached from the perspective of the public world of appearances. The principal idea was that only in the light of the public realm could things and persons gain their full meaning and significance by appearing and being seen from a plurality of perspectives. While human beings naturally also appear in private as physical beings, it is only through public appearance that they can disclose who, and not merely what, they are (Arendt, 1998, pp. 179-180). And yet, this reality can be guaranteed only on condition that one can also hide from the public light - " [a] life spent entirely in public [...] becomes, as we would say, shallow. While it retains its visibility, it loses the quality of rising into sight from some darker ground which must remain hidden if it is not to lose its depth in a very real, non-subjective sense" (Arendt, 1998, p. 71). There is a dynamic at play in which public appearance and the possibility for privacy feed each other. Some activities Arendt deems merely private. However, mostly - and this also concerns the activity of thinking - she suggests channels for making non-public aspects of life fit for appearance in order to gain objectivity and possible permanence: "even the greatest forces of intimate life - the passions of the heart, the thoughts of the mind, the delights of the senses - lead an uncertain, shadowy kind of existence unless and until they are transformed, deprivatized and deindividualized, as it were, into a shape to fit them for public appearance" (Arendt, 1998, p. 50). Such dynamic of in/visibility provides potent material for political thought, and authors building on Arendt have indeed used it to analyze such themes as power/resistance (Gordon, 2002), identity (Hammer, 1997), dignity and ethics (Assy, 2004), and sans papiers (Borren, 2008).

\footnotetext{
${ }^{9}$ Arendt's emphasis on the coincident nature of being and appearing is arguably indebted, but not reducible, to Heidegger's thinking on the subject, especially in Introduction to Metaphysics. See Villa, 1996, p. 152, and Assy, 2004, p. $298 \mathrm{ff}$.
} 
The relationship between visibility and invisibility is a theme that plays a central role in various parts of Arendt's work. "Nothing and nobody," Arendt writes in The Life of the Mind, "exists in this world whose very being does not presuppose a spectator" (LMT, p. 19). In exploring this path further, we follow Bethânia Assy who has argued that LMT "relies on visibility" (Assy, 2004, p. 295). Yet, it is important to note from the very beginning that not only visibility, but also invisibility is central to understanding Arendt's argument in LMT: "Seen from the perspective of the world of appearances and the activities conditioned by it, the main characteristic of mental activities is their invisibility" (LMT, p. 71). Thinking (together with other mental activities) differs radically from all other human faculties in that even in full actuality they remain non-manifest (LMT, p. 72). This is well illuminated by an oft-cited story about Heraclitus, told by Aristotle and commented upon by Martin Heidegger among others. It describes the arrival of a group of strangers who were eager to meet the famous thinker and, in Heidegger's words, "to catch sight of him perchance at that very moment when, sunk in profound meditation, he is thinking" (Heidegger, 1993, p. 257). However, instead of seeing something extraordinary, the visitors encounter Heraclitus in the most banal situation, warming himself at the kitchen furnace. Somewhat disappointed and hesitating at the threshold, the foreigners are, the story goes, encouraged by Heraclitus with the utterance: "here too the divinities are present" (Aristotle, trans. 2001, A, 5, 645a17ff; Heidegger, 1993, p. 256).

How does the existing literature on Hannah Arendt approach von Trotta's visualization of political thinking and Arendt's idiosyncratic understanding of in/visibility? Barbara Sukowa "seems to be a philosopher locked in deep thought" - in Kaplan's (2013) view, then, the visualization of thinking is the actor's achievement, not the director's (Lilla disagrees, see above). Likewise, Rieff, joining those critics who praise the film and its director for "portraying thinking on-screen in a manner that isn't boring in the slightest," that is "very interesting and original," praises Sukowa - and von Trotta for both casting Sukowa and using "tricks" and "visual gimmick[s]" when representing thinking (are these "gimmicks" what makes the representation of thinking "very interesting and original"?). Not surprisingly, Brody disagrees (see above) and Steven (2014) is not convinced either: Thinking, in Hannah Arendt, is “externalise[d] ... through social interaction. If Arendt thinks, we don't see it, and we don't see it because melodrama constantly obviates against the very possibility of its existence." The strongest defense comes from Berkowitz (2013a) who, speaking not only for himself but for the "audience" and "us," concludes that "Hannah Arendt's" burning cigarette, rather than becoming "an empty cipher, an obvious symbol," intensifies "her silent intensity, ... strik[ing] the viewer, propel[ing] us to think with Arendt about what she is observing and its implications. 
The audience is thus transformed, moving from observing Arendt to thinking with her." The critics, thus, are divided, not only as to the question of what visual strategies the director primarily applies - externalizing thinking through (melodramatic) interaction or privatizing it through depictions of loneliness - but also as to the question of whether or not her strategies succeeded. What is needed, then, is a more systematic approach to von Trotta's visual representations of political thinking, developed in light of Arendt's writings, to move beyond rather empty and analytically weak assessments such as some of the above.

\section{Hannah Arendt - a Visual Typology of Political Thinking}

As we established above, thinking is difficult to make visible; by nature, it hides from appearance. ${ }^{10}$ In her work, Arendt mentions two panaceas to this predicament: verbal communication and writing. In The Human Condition, Arendt notes that thinking - in and by itself an endless, result-less process of reflection - requires intervals of not thinking, during which time the thinker has to write down what she or he has already thought (Arendt, 1998, p. 76, 90). Writing, and the visualization of writing, then, signify the preceding process of thinking, the temporary suspension of thinking during the writing process and the resumption of thinking once the writing is done. Accordingly, in the film, "Hannah Arendt's" process of thinking continues after typing scenes: typing does not signify the end of thinking as, for Arendt, there is no such thing as the end of thinking: thinking is potentially infinite. ${ }^{11}$ Thus, it cannot even be said that the process of thinking was over once the series of articles was published; even after publication, thinking will most likely have continued, as Arendt's work indicates. However, writing can also function as a platform for developing thinking about an issue. In an interview with Günter Gaus, Arendt noted that for her "writing is a matter of seeking understanding, part of the process of understanding [in which] certain things get formulated" (Arendt, 1994, p. 3). Further clarification occurs in her Preface to Between Past and Future where Arendt writes about "exercises in thought," referring to the experience-based and experimental nature of thinking, and invokes the essay form as a literary form that has "natural

\footnotetext{
${ }^{10}$ This is not because thinking would be isolated from the world of appearances. Arendt underscored the fact that thinking can only arise "out of incidents of living experience and must be bound to them as the only guidepost by which to take its bearings" (Arendt, 2006a, p. 14).

${ }^{11}$ Thus, removing a piece of paper from the typewriter, carrying it to "Heinrich Blücher" in the adjacent room, putting the paper on the desk and declaring "Voilà, monsieur" before turning and leaving the room (1:04:23) does not signify the end of thinking on "Hannah Arendt's" part. This becomes clear later in the film when she critically engages with her earlier assessment: "Everyone is trying to prove me wrong. But no one noticed my one real mistake. Evil cannot be both banal and radical at once. Evil is only ever extreme. It's never radical. Only good can be profound and radical" (1:41:24-1:41:54). It is arguable, however, that the director lost interest in the visualization of political thinking in the film's second half, turning her attention instead to "the controversy."
} 
affinities" with this kind of thinking (Arendt, 2006, p. 14-15). The written form easily betrays the tendency of thinking to undo its own results by giving thoughts a fixed form. Arendt's preference of the essay as a literary form was her way of navigating past this problem: the essay, as an experimental, experiential, and tentative platform, provides a basis for theorizing that acknowledges the fact that the "need to think can be satisfied only through thinking" (Arendt, 2003a, p. 163) - in short, it was Arendt's way of presenting her thought in an open-ended manner, with the intention of provoking further thought. But writing as such can hardly function as a vehicle for visualizing thinking in the movie. In addition to the writing scenes, we identify two main strands of representing thinking in Hannah Arendt, following what Jon Nixon has called the Janus-faced character of thought, the fact that it turns "both inward towards solitary reflection and outward towards dialogue and discourse" (Nixon, 2015, p. 163). The next sections will therefore focus on the representation of thinking in von Trotta's Hannah Arendt by discussing the solitary, invisible aspects of thinking (dubbed internalization), on the one hand, and the slightly less successful attempts at externalization in dialogue.

\section{Internalization}

We want to suggest that Arendt's political thinking is visualized throughout the film according to four tropes. These tropes are not mutually exclusive but appear in different combinations: first, smoking; secondly, staring (out of the window or at the ceiling); thirdly, lying on the couch, often remembering scenes from the trial; and, fourthly, talking with others (see below). Tropes one and two seem rather straightforward as the above quotation - "A woman stares at the ceiling, smoking a cigarette. This is Hannah Arendt, thinking" - indicates. It is worth noting, however, that they relate to one of the positive outer manifestations of thought mentioned by Arendt. Namely, the idiomatic "stop and think," i.e. the fact that while thinking, "we stop whatever else we may have been doing, and [...] are unable to do anything but think" (Arendt, 2003a, p. 105). This can be called a negative approach to the visualization of thinking: while the thinking process as such - or its tentative results - lack any visible concreteness, the existence of thinking is alluded to by the absence of other activities. "The only outward manifestation of the mind is absentmindedness" (LMT, p. 74).

Apparently, Arendt herself was particularly expressive on this score, as Mary McCarthy recalled: "Hannah is the only person I have ever watched think. She lay motionless on a sofa or a day bed, arms folded behind her head, eyes shut but occasionally opening to stare upward" (McCarthy, 1976). As can be inferred from the Heraclitus story above, this can hardly be fully satisfactory. It is "something entirely negative which in no way hints at what is actually happening within us" (LMT, 
p. 72). In the visual language of Hannah Arendt, we then do have an indication of a thinking process in action. However, the process itself lacks any capability of being seen or heard which, while denying the audience any participation in the activity of thought taking place on the screen, may also activate the audience's imagination: if something is hidden from view, "its power as a concealed image outstrips anything it could have achieved by being shown" (Mitchell, 2011, p. 63). There is another role potentially fulfilled by such imaginary. It gives the audience a moderate compensation for the defect of cinema noted by Walter Benjamin when he complained that the movie screen - as opposed to a painting - does not provide time for associative reflection: "No sooner has his eye grasped a scene than it is already changed." Watching constantly moving images, one could argue, provides no better ground for thinking than participating in vita activa. In order to be able to really think one needs to withdraw not only from activity but even active perception of movement. By default, cinema is unable to provide space for such withdrawal. Benjamin further quotes Georges Duhamel saying "My thoughts have been replaced by moving images" (Benjamin, 1936/2007, p. 238). Indeed, spectators are "prisoners of the director's sense of time" (MorrisSuzuki, 2005, p. 124). The recurrent trope of smoking or looking out of the window could possibly overcome this general characteristic of film because nothing is moving on screen except the cigarette's smoke. Thus, von Trotta's tropes one and two reflect neither what Gilles Deleuze called "cinema of action" making the viewer ponder "What are we going to see in the next image?" nor "cinema of seeing" making the spectator ask "What is there to see in the image?" (Deleuze quoted in Shapiro, 2015, p. 141) Rather, these tropes represent what could be called cinema of thinking.

The third and the fourth tropes deserve closer attention because it is here that discussion of both the role and function of memory and the relationship between thinking and speaking becomes necessary. The role of remembrance illuminates an additional aspect of in/visibility in thinking. That is, while rooted in experiences from and of the world, thinking also never deals with objects that are directly perceived: "every thought is an after-thought" (LMT, p. 78). Hence, the phenomena one thinks about are always strictly speaking absent, and present to the mind only thanks to the power of imagination which re-presents objects in the form of an image (Arendt, 2003a, p. 165; LMT, p. 77, 85). Thinking and representation join hands in the sense that both are based on memory: they always come after (Huyssen, 1995, p. 2). Thinking requires withdrawalnot from the world as such, but from the "the world's being present to the senses" (LMT, p. 75). In order to think about somebody, say, Eichmann, "he must be removed from our senses; so long as we are together with him we don't think of him - though we may gather impressions that later become food for thought" (Arendt, 2003a, p. 165). This not only further highlights the important 
function of the slow-paced thinking scenes, but also more generally discloses the role of remembrance in thinking: "Remembrance has a natural affinity to thought; all thoughts, as I have said, are after-thoughts. Thought-trains rise naturally, almost automatically, out of re-remembering, without any break" (Arendt, 1978b, p. 37). Imitating this process on the screen is more difficult than one would immediately envisage, however. For the mental images Arendt - following Augustine says remembrance produces for thinking are not copies of the actual experiences. They are "filtered," as it were, through imagination, which turns passive memories into thought-stuff. The role of imagination introduces a poetic element into remembrance. It does so by combining elements from the past, setting them into dialogue with each other and with visions of the future. Thinking takes place in the "gap between past and future," in which the thinker struggles with the forces of the past and the forces of the future. The images of the past that go through this struggle do not remain untouched, but in the words of The Tempest often cited by Arendt, "doth suffer a seachange / into something rich and strange" (The Tempest, I, 2; LMT, p. 212).

\section{Externalization}

In addition to absentmindedness - suggesting an invisible and inaudible dialogue between me and myself - thinking also turns outwards positively in actual and concrete conversation. It is this intimate relationship between speech and thinking that sets the latter apart from wor(l)dless contemplation. In The Life of the Mind (LMT, p. 32), Arendt insists that "Thought without speech is inconceivable." Speech or, more broadly, language provides the only possible outward manifestation for thoughts. It can also manifest thoughtlessness, as we pointed out above. To be precise, thinking not only needs speech for manifestation, it also needs speech to be activated at all (LMT, p. 121). The trouble here is that the vocabulary of any language is developed for the purposes of the life in the world of appearances, and lacks a direct way to engage with the invisible winds of thought. Hence thinking works and expresses itself through metaphors. True to its etymological origins, the metaphor "carries over" (metapherein) from the invisible to the world of appearances. Poetic, metaphorical language, as opposed to stock-phrases, is the trademark of thinking.

Thinking is not speechless contemplation; thinking always has the nature of two-in-one - i.e. of inner dialogue, reaching into an anticipated dialogue with others. While it is certainly true that thinking takes place in solitude, it is also mutually dependent on our ability to engage in dialogue with others - with friends: "I first talk with others before I talk with myself, examining whatever the joint talk may have been about, and then discover that I can conduct a dialogue not only with others 
but with myself as well" (LMT, p. 189; see also Nixon, 2015). Here, and even more explicitly in a Denktagebuch entry from 1968, Arendt reverses Aristotle's view of the friend as another self. It is because we have dialogue with others that we are capable of deliberating with ourselves - i.e. capable of thinking (Arendt, 2003b, p. 688). In its original Socratic sense, dialogue - dialegesthai refers to the activity of thinking and talking something through with someone, not in order to present a philosophical truth, but in order to bring forth the truth in perspectives (doxai) (Arendt, 2005, pp. 12-15). This is also what she admired for instance in Karl Jaspers, her teacher, life-long friend, and companion in thought (some of their dialogue is documented in the voluminous exchange of letters between the two). In Jaspers, Arendt once wrote, thought processes are presented "in a way that is always experimental and never rigidly fixed, having at the same time the character of suggestions that induce others to join with him in thought" (Arendt, 1994, p. 183). As Babich (2014, p. 25) points out in her discussion about the film: "we will need more than the lonely business of thought as Heidegger spoke of the thinker in the singular, to think about thinking. As the ancients knew and as Arendt learned from Jaspers, thinking can only be done in a community of other human beings who together form a community, a world."

It is on this score that we conceive von Trotta's Hannah Arendt unable to harvest the full potential available in its subject matter. When it comes to cinematic strategy, the above description of the mutual dependency of thinking and dialogue opens two distinct possibilities. On the one hand, the invisible, inaudible, non-appearing character of thought can be partly overcome by making audible the inner dialogue of the protagonist. On the other, concrete dialogue with others is also indispensable for thought-processes. Not only could such dialogue then be one of the vehicles for making audible what goes on in the mind of the protagonist, it is also a valuable aspect of the activity of thinking in and by itself. Now, there is certainly no lack of dialogue as such in the movie. To translate the soundless dialogue into an audible conversation was one of director von Trotta's strategies to circumvent the invisibility of thinking and to involve the audience in "Hannah Arendt's" process of thinking. However, much of the conversation falls short of the kind of truthful dialogue we described above. One of the reasons for this is the depth and multifacetedness of the characters, which clearly favors "Hannah Arendt." By reducing every character except Arendt to caricatures, the director forgoes the possibility of representing the development of Arendt's thinking as a process happening in critical dialogue with others.

This missed opportunity for on-screen dialogue also transforms into a lack of dialogue as a call-andresponse in which viewers, too, could participate; therefore the occasionally somewhat didactic 
monologue that is Hannah Arendt. Therefore, too, the lack of irony and social critique both of which are, as Mark Steven notes, integral components of New German Cinema from which both von Trotta and Sukowa emerged (Steven, 2014). In the film, Arendt's critics appear as "irrational, defensive Jews who, unlike Arendt, refuse to think about the uncomfortable complexities of the Nazi experience, whether out of shame or omertă" (Lilla, 2013). Certainly, Azoulay is correct in identifying the "disturbing consensus" among the Israelis and other instances of dogmatic responses to Eichmann - and Arendt's resistance to them - as indeed integral parts of the thinking-process (Azoulay, 2015, p. 128). However, it is especially the representation of Arendt's friends - with the exception of Hans Jonas - that is insufficient. Most of her interlocutors do not even appear as sparring partners; they appear as intellectual nobodies. Other commentators have also noted that the film fails to capture Mary McCarthy's “enormously cultivated sensibility and breadth of knowledge"; she remains excluded from the thinking sphere of Arendt and the film, as she is from the German discussion in the cocktail party in its beginning (Rieff, 2014; Steinberg, 2015, p. 62). Rieff also complains that the film misrepresents The New Yorker's editor William Shawn and that it reduces "Kurt Blumenfeld," substituting in the film for Gershom Scholem, to a "doddering sentimentalist" (Rieff, 2014). And it is doubtful, too, if "Heinrich Blücher" lives up to the characterizations of him as a Socratic personality par excellence, an exemplary representative of thinking's outward aspect, and "an extraordinarily mental creature [...] shouting philosophy at you in the sweetest kind of way" (Kazin, 1982, p. 3). The absence of Karl Jaspers further adds to this feature of the film.

In short, the conversations "Hannah Arendt" is engaged in are not conversations among equals. The lack of interest in an adequate representation of Arendt's intellectual environment is not a problem in itself because Hannah Arendt does not claim to be a documentary. However, it affects the fourth trope identified above: talking with others which, for Arendt, is never just talk. The lack of any serious dialogue in the film - despite the presence, in Arendt's life and in the film, of intellectual heavy-weights - is a major problem: it misrepresents Arendt's approach to thinking and it reduces spectators to mere recipients of Arendt's introspectively developed and, therefore, necessarily incomplete and unfinished thoughts. Perhaps something like this is also suggested by Michael Steinberg, who notes that the film's success in seeing thinking is more evident than its effort of hearing it (Steinberg, 2015, p. 64). The purpose of "Hannah Arendt's" conversations, in the process of which she shares with others what she thinks about Eichmann, seem - at least at times - more as attempts to receive confirmation, even though she never seems to need confirmation. For example, 
from 1:03:32 to 1:03:56 "Hannah Arendt" reads a paragraph from the manuscript to her assistant, "Lotte Köhler":

"Hannah Arendt" Listen to this. I've changed the paragraph. 'Evil is supposed to be something demonic. Its incarnation is Satan. But in the case of Eichmann, one could find no such trace of satanic "greatness." He was simply unable to think.'

"Lotte Köhler": $\quad$ That's great.

"Hannah Arendt": $\quad$ It's better, right?

"Lotte Köhler": $\quad$ Yes.

"Hannah Arendt" knows that she understood Eichmann appropriately - that she got him right; hence, the frequent accusations in the film of arrogance. There is no real use made of the screentime given to Arendt's circle of friends, who could have served as real interlocutors, even making Arendt change her mind or reformulate her position. This never happens. What makes the issue more serious, from the perspective of what we above identified as a cinema of thinking, is that the lack of balanced dialogue also deprives the audience of the possibility of playing a call-andresponse role. The dialogue, then, falls short of presenting us with provocations and time to respond. It turns Hannah/Arendt into a preacher instead of a Socratic gadfly, provoking thought in others by the means of dialegesthai.

\section{Conclusion: Hannah Arendt in light of Hannah Arendt's writings}

We have noted that thinking is related to invisibility in two ways. Thinking both deals with invisibles and is itself invisible (on this point, see also Burch, 2012, pp. 11-12). Any attempt at representation of thinking must then carefully navigate the poetics of visualizing the invisible. We discussed von Trotta's usage of smoking, staring, lying down and remembering, and discussing with others as tropes for representing political thought. We argued that von Trotta's representation of what we called the external aspects of thought failed to reach the plane where the dialogical nature of thought would have become fully manifest. However, the visual language of the film is more successful regarding the "internal" aspects of thought. Seizing on the power of the invisible and the character of stop-and-think, the film opens up a space for the thought-process to initiate.

Its invisibility notwithstanding, thinking is by no means isolated from the world of appearances: it merely withdraws temporarily from an active involvement in the worldly affairs in order to be able to step into the position of a spectator and think what it is that we are doing. That human beings are 
able to hide from the common world is the pre-condition for both emotional and thoughtful aspects of life. We need the "darkness" of non-publicity. In rare "boundary situations," the wind of thought can even activate the ability to tell right from wrong, at least to the extent of preventing one from taking part in wrong-doing. This matter is also related to Arendt's presentation of the faculty of judgment, whose relation to thinking she did not have time to explicate. In $L M T$ she notes that “Thinking deals with [...] things that are absent; judging always concerns particulars [...] judging [...] realizes thinking, makes it manifest in the world of appearances, where I am never alone and always too busy to be able to think. The manifestation of the wind of thought is not knowledge; it is the ability to tell right from wrong, beautiful from ugly" (LMT, p. 193; Arendt, 2003a, p. 105).

Engaging with experimental modes of visualization might also prove thought-provoking in the contemporary context. For Arendt, we are living in "dark times": public spaces have dimmed, and this lack of public illumination is further intensified by "highly efficient talk and double-talk." "If it is the function of the public realm to throw light on the affairs of men by providing a space of appearances in which they can show in deed and word, for better and worse, who they are and what they can do, then darkness has come when this light is extinguished by 'credibility gaps' and 'invisible government', by speech that does not disclose what is but sweeps it under the carpet" (Arendt, 1968, p. viii). Faced with such invisible government - and assuming we wish to resist its replacement with the kind of demagoguery and outright lying we have increasingly witnessed recently - we need films like Hannah Arendt. The eminently political character of the film, for us, emerges from its engagement with the intangible, abstract, and invisible that might open new channels for critical thought about contemporary politics. It reminds us of the political importance of thinking. This cinema of thinking seems to suggest that the most thought-provoking imaginary is not necessarily one that "uncovers" the unseen, but rather forces us to engage with the invisible. 


\section{References}

Arendt, H. (1968). Men in Dark Times. New York: Harcourt Brace \& Co.

Arendt, H. (1978a). The Life of the Mind. One, Thinking (LMT). New York: Harcourt Brace Jovanovich.

Arendt, H. (1978b). The Life of the Mind. Two, Willing. New York: Harcourt Brace Jovanovich.

Arendt, H. (1979). On Hannah Arendt. In: M.A. Hill (Ed.), Hannah Arendt: The Recovery of the Public World (pp. 301-339). New York: St. Martin's.

Arendt, H. (1994). Essays in Understanding, 1930-1954: Formation, Exile, and Totalitarianism. New York: Schocken.

Arendt, H. (1958/1998). The Human Condition. Chicago: The University of Chicago Press.

Arendt, H. (2003a). Responsibility and Judgment. New York: Schocken

Arendt, H. (2003b). Denktagebuch: 1950-1973. Munich: Piper.

Arendt, H. (2005). The Promise of Politics. New York: Schocken.

Arendt, H. (2006). Between Past and Future. New York: Schocken.

Arendt, H. \& Heidegger, M. (2004). Letters, 1924-1975. New York: Schocken.

Aristotle (2001). On the Parts of Animals. (W. Ogle, Trans.). Blacksburg: Virginia Tech.

Assheuer, T. (2013). Ist das Böse wirklich banal? Die Filmregisseurin Margarethe von Trotta huldigt der Philosophin Hannah Arendt - und verschleiert ihre Irrtümer. Die Zeit, 10 January. Retrieved April 19, 2015 from http://www.zeit.de/2013/03/Film-Hannah-Arendt-Margarethe-vonTrotta/seite-2

Assy, B. (2004). Prolegomenon for an ethics of visibility in Hannah Arendt. Kriterion: Revista de Filosofia, 45, 294-320.

Azoulay, A. (2015). Arendt's Guidelines for a Fictionalized Cinematic Portrait. differences: A Journal of Feminist Cultural Studies, 26, 2, 121-131.

Babich, B. (2014). Arendt's Radical Good and the Banality of Evil: Echoes of Scholem and Jaspers in Margarethe von Trotta's Hannah Arendt. Existenz, 9, 13-26.

Benjamin, W. (1936/2007). Illuminations: Essays and Reflections. New York: Schocken.

Berkowitz, R. (2013a). Lonely Thinking. The Paris Review, 30 May. Retrieved April 17, 2014 from http://www.theparisreview.org/blog/2013/05/30/lonely-thinking-hannah-arendt-on-film

Berkowitz, R. (2013b). Misreading "Eichmann in Jerusalem". New York Times, 7 July. Retrieved April 19, 2015 from http://www.opinionator.blogs.nytimes.com/2013/07/07/misreading-hannaharendts-eichmann-in-jerusalem/?_r=0 
Borren, M. (2008). Towards an Arendtian Politics of In/Visibility: On Stateless Refugees and Undocumented Migrants. Ethical Perspectives: Journal of the European Ethics Network, 15, 213-237.

Brody, R. (2013). "Hannah Arendt" and the Glorification of Thinking. The New Yorker, 31 May. Retrieved April 17, 2014 from http://www.newyorker.com/online/blogs/movies/2013/05/hannaharendt-and-the-glorification-of-thinking.html

Burch, R. (2011). Recalling Arendt on Thinking. In A. Yeatman, P. Hansen, M. Zolkos, \& C. Barbour (Eds.), Action and Appearance: Ethics and the Politics of Writing in Hannah Arendt (pp. 10-24). New York: Continuum.

Connolly, W.E. (2002). Neuropolitics: Thinking, Culture, Speed. Minneapolis: University of Minnesota Press.

Dyer, G. (2007). The Ongoing Moment. London: Abacus.

Gordon, N. (2002). On Visibility and Power: An Arendtian Corrective of Foucault. Human Studies, $25,125-145$.

Hammer, D. (1997). Hannah Arendt, identity and the politics of visibility. Contemporary Politics, 3, 321-339.

Heidegger, M. (1977/1993). Basic Writings. From Being and Time to The Task of Thinking. Edited by David Farell Krell. New York: HarperCollins.

Huyssen, A. (1995). Twilight Memories: Marking Time in a Culture of Amnesia. New York and London: Routledge.

Hyvönen, A.-E. (2014). Tentative Lessons of Experience: Arendt, Essayism, and "the Social" Reconsidered. Political Theory 42:5, 569-589.

Kaplan, F. (2013). The Woman Who Saw Banality in Evil. New York Times, 24 May. Retrieved April 17, 2014 from http://www.nytimes.com/2013/05/26/moviews/hannah-arendt-directed-bymargarethe-von-trotta.html? Pagewanted=2

Kazin, A. (1982). Woman in Dark Times. The New York Review of Books, 29:11. June 24.

Lilla, M. (2013). Arendt \& Eichmann: The New Truth. The New York Review of Books, 21

November. Retrieved April 17, 2014 from

<http://www.nybooks.com/articles/archives/2013/nov/21/arendt-eichmann-new-truth

Lindroos, K. \& Möller, F. (forthcoming). Witnessing in Contemporary Art and Politics. In K.

Lindroos \& F. Möller (Eds.), Art as a Political Witness (Leverkusen: Barbara Budrich Publishers).

Lybarger, D. (2013). The Eternal Student: Margarethe von Trotta on Hannah Arendt. Huffington Post, 31 May. Retrieved April 17, 2014 from http://www.huffingtonpost.com/dan-lybarger/theeternal-student-marga_b_3360870.html 
McCarthy, M. (1976). Saying Good-bye to Hannah. The New York Review of Books, January 22, issue $21 / 22$.

Mitchell, W.J.T. (2011). Cloning Terror: The War of Images, 9/11 to the Present. Chicago and London: The University of Chicago Press.

Morris-Suzuki, T. (2005). The Past Within Us: Media, Memory, History. London and New York: Verso.

Nixon, J. (2015). Hannah Arendt and the Politics of Friendship. London: Bloomsbury.

Rieff, D. (2013). Hannah and Her Admirers: Margarethe von Trotta's biopic of Hannah Arendt is a film about ideas that remains intellectually detached from them. The Nation, 9 December. Retrieved April 17, 2014 from http://www.thenation.com/article/177277/hannah-and-her-admirers

Shapiro, M.J. (2009). Cinematic Geopolitics. London and New York: Routledge.

Shapiro, M.J. (2015). War Crimes, Atrocity, and Justice. Cambridge and Malden: Polity Press.

Steinberg, M.P. (2015). Seeing Hearing Thinking: Introducing the differences Dossier on Margarethe von Trotta's Hannah Arendt. differences: A Journal of Feminist Cultural Studies 26, 2, 61-69.

Steven, M. (2014). Review: thinking on screen - von Trotta's "Hannah Arendt". The Conversation, 18 February. Retrieved April 17, 2014 from http://theconversation.com/review-thinking-on-screenvon-trottas-hannah-arendt-23026

Sari, Y (2014). Review/synopsis: Hannah Arendt. Philosophy Now: A Journal of Ideas, 100 (January/February). Available at: https://philosophynow.org/issues/100/Hannah_Arendt.

Villa, D. R. (1996). Arendt and Heidegger: The Fate of the Political. Princeton: Princeton University Press. 